\title{
Determinants of waste generation per capita in Catalonia (North-eastern Spain): the role of seasonal population
}

\author{
Òscar Saladié ${ }^{1}$
}

\begin{abstract}
Seasonal population is not taken into account in waste management policies and regional differences in waste generation per capita are magnified. Here I analyze the differences among the Catalan counties (North-eastern Spain) and I compare the results if seasonal population is added or not to the resident people. Waste generation per capita in tourist areas is overestimated and actually the differences among the counties are lower than those indicated in the official data. Only reliable data will allow determining the reasons of differences in waste generation per capita and stablishing more precise objectives in waste management policies. There is a positive correlation between municipal waste generation per capita and the services sector's contribution to GDP, a negative correlation with the percentage of population over 64 and no correlation with income per capita. Finally, taking into account territorial factors, the lowest waste generation per capita corresponds to counties with very low population densities located in inland Catalonia.
\end{abstract}

Key words: Municipal waste management, seasonal population, determinants of waste generation per capita, Catalonia

\section{Introduction}

There are broad typologies of waste, all with varying behaviour related to environmental agents, potential evolution over time and impacts on environment and human health. The natural ecosystem's capacity to receive and incorporate waste is limited, and exceeding it can become a serious environmental problem. Waste can be harmful to human health and animal and plant life and may also affect soil, ground water and air quality, including global warming and inadequate management can compromise the sustainability of our development. Waste is classified in three main groups according to its toxicity and hazard: inert, special and non-special. In 2002, the European Waste Inventory (EWI) came into force and twenty categories were established, indicating their required management: recovery/recycling, treatment and/or refuse disposal. The last category in the EWI (number 20) covers municipal solid waste, including household waste and waste generated by commerce, services and institutions.

Municipal solid waste management has improved significantly in recent decades (collection, transport and final disposal), especially if compared with when waste was dumped in inappropriate areas and in some cases, burned in the open (Saladié, 2011a; Atencio Pérez et al., 2013). Nevertheless, open dumping is still how waste is managed in some developing regions (Buenrostro and Bocco, 2003; Bernardes and Günther, 2014). Final disposal in a modern landfill or in an incinerator also generates environmental 
impacts, which are more significant in landfills than in incinerators with energy recovery (Morselli et al., 2008; Bovea et al., 2010; Assamoi and Lawryshyn, 2012). Furthermore, the selection of an appropriate site for a landfill is not an easy task, as indicated, among others, by Bautista and Pereira (2006), Khadivi and Fatemi Ghomi (2012) and Ersoy et al. (2013), especially considering the social perception of this kind of infrastructure (De Feo and Williams, 2013).

The main objective of waste management policies is to prevent and reduce waste generation (Goddard, 1995; Salhofer et al., 2008; Gentil et al., 2011). A second goal, which is closely linked to the previous one, is to separately collect the different fractions of municipal waste and treat them for recycling or reuse (Ferrao et al. (2014), with prior repair in some cases. These goals will not be achieved without suitable and planned waste management.

Determining the factors that influence waste generation is crucial for applying appropriate policies to prevent generation. Municipal solid waste generation is a consequence of the consumption of goods. However, consumption patterns are not uniform and there are significant differences worldwide in waste generation per capita (Shekdar, 2009; Purcell and Magette, 2009). These differences in consumption patterns are due to socioeconomic, demographic, territorial and environmental factors, and their relationship with waste generation has been extensively analysed in the academic literature (Beigl et al., 2008; Oribe-Garcia et al., 2015). A strong relation has been detected with income levels (Abu Qdais et al., 1997; Buenrostro et al., 2001; Gómez et al., 2008; Qu et al., 2009; Gellynck et al., 2011), unemployment rates (Keser et al. 2012), contribution of the services sector to GDP (Saladié, 2011b), education levels (Getahun et al., 2012), waste disposal fees (Hockett et al., 1995; Sterner and Bartelings, 1999), size of households (Qu et al., 2009; Lebersorger and Beigl, 2011), and population density and altitude (Passarini et al., 2011). However, each of the studies mentioned focuses on a specific location (cities, regions or countries) and the variables analysed may bear no relation to waste generation in other territories. No significant correlation is found between income and waste generation per capita in the studies performed by Dahlén (2009) and Getahun et al. (2012).

Policies aiming to reduce waste generation should be defined according to the reasons explaining its generation in each region (Keser et al., 2012). All the stakeholders in waste management must contribute to changing consumption patterns. A change in behaviour must be achieved, preferably in a non-compulsory way, and because people are concerned about environmental issues. A gradual shift is always better than an abrupt change due to external factors, such as a reduction in economic activity (Cole et al., 2014).

The first step is to obtain quality data on total and per capita waste generation. This data will allow us to carry out a reliable analysis of trends in the same territory (at local, regional or national level) and compare results from different territories. The availability of accurate data is also necessary for predicting waste generation and composition (Chowdhury 2009; Lebersorger and Beigl, 2011), although this is not always possible, as noted by Dahlén et al. (2009) in Sweden and Boer et al. (2010) in Poland.

Municipal solid waste collection in Catalonia (north-eastern Spain) amounted to just over 3.7 million tonnes in 2012, whereas in 2000 it was less than 3.5 million tonnes. This 
indicates a 7.5\% increase in 12 years. Nevertheless, since its peak in 2007 (4.3 million tonnes), the total amount has decreased slightly. The population increased by $20.9 \%$ over the same period (2000-2012), from 6.3 to 7.5 million inhabitants. In terms of per capita generation, this means $1.51 \mathrm{~kg} /$ day in 2000 and $1.35 \mathrm{~kg} /$ day in 2012 . The highest value for the period corresponds to 2007 with $1.64 \mathrm{~kg} /$ inhabitant/day. The target established for 2012 by the Catalan Municipal Waste Management Program (PROGREMIC 2006) was $1.48 \mathrm{~kg}$. Meanwhile the selective collection of different waste represented in 2000 only $14 \%$ of the total, while in 2012 it was 39.1\%. Most municipal waste is sent to final disposal infrastructures: incineration plant or landfill.

Municipal solid waste generated by tourists has traditionally been attributed to the resident population when calculating generation per capita and, as pointed out by Passarini et al. (2001), this can affect regions with high levels of tourism. Fluctuations in municipal solid waste during the year have been used to calculate the seasonal population of territories in which tourism activity is important, as described by Mateu (2003), Sajani et al. (2005) and Perea-Milla et al. (2007).

Tourism is one of the most important economic activities in Catalonia. Spain is the fourth tourist destination in the world and Catalonia is the Spanish region that receives the lion's share of these international tourists as well as tourists from the rest of Spain. In 2012 Catalonia received almost 15 million international tourists and over 5 million from the rest of Spain (DGT 2013). Tourists spend money during their stays but they also consume resources (energy and water) and generate both sewage and solid waste.

Taking all this information as a starting point, the main objective of this paper is to assess the differences in municipal waste generation per capita in the forty-one Catalan counties (Figure 1) in 2012 and to demonstrate that these differences are magnified because seasonal population is not taken into account. For this reason, two sets of values have been used. For the first value, municipal waste generation per capita is calculated using only the resident population. For the second, the seasonal population equivalent to annual full-time population is added to the resident population and a new set of waste generation per capita data generated. A second objective is to assess whether the differences found in municipal waste generation per capita between counties are related to a set of selected territorial, socioeconomic and demographic variables.

The rest of the paper is organized as follows. Section 2 is devoted to explaining the data-gathering process and methodology. The results and discussion are presented in Section 3, and finally Section 4 shows our conclusions.

\section{Material and methods}

Municipal solid waste (MSW) management in Spain is the competency of the municipalities. However, according to Ley 10/1998 de residuos, the autonomous regions in Spain must draw up a management program to minimize the amount of waste, increase reuse and recycling rates and develop a suitable network of infrastructures to enable the final disposal of waste. In the case of Catalonia, this is the PROGREMIC mentioned earlier.

Annual data for municipal solid waste generation for Catalonia as a whole and for two smaller scale areas (counties and municipalities) can be obtained from the 


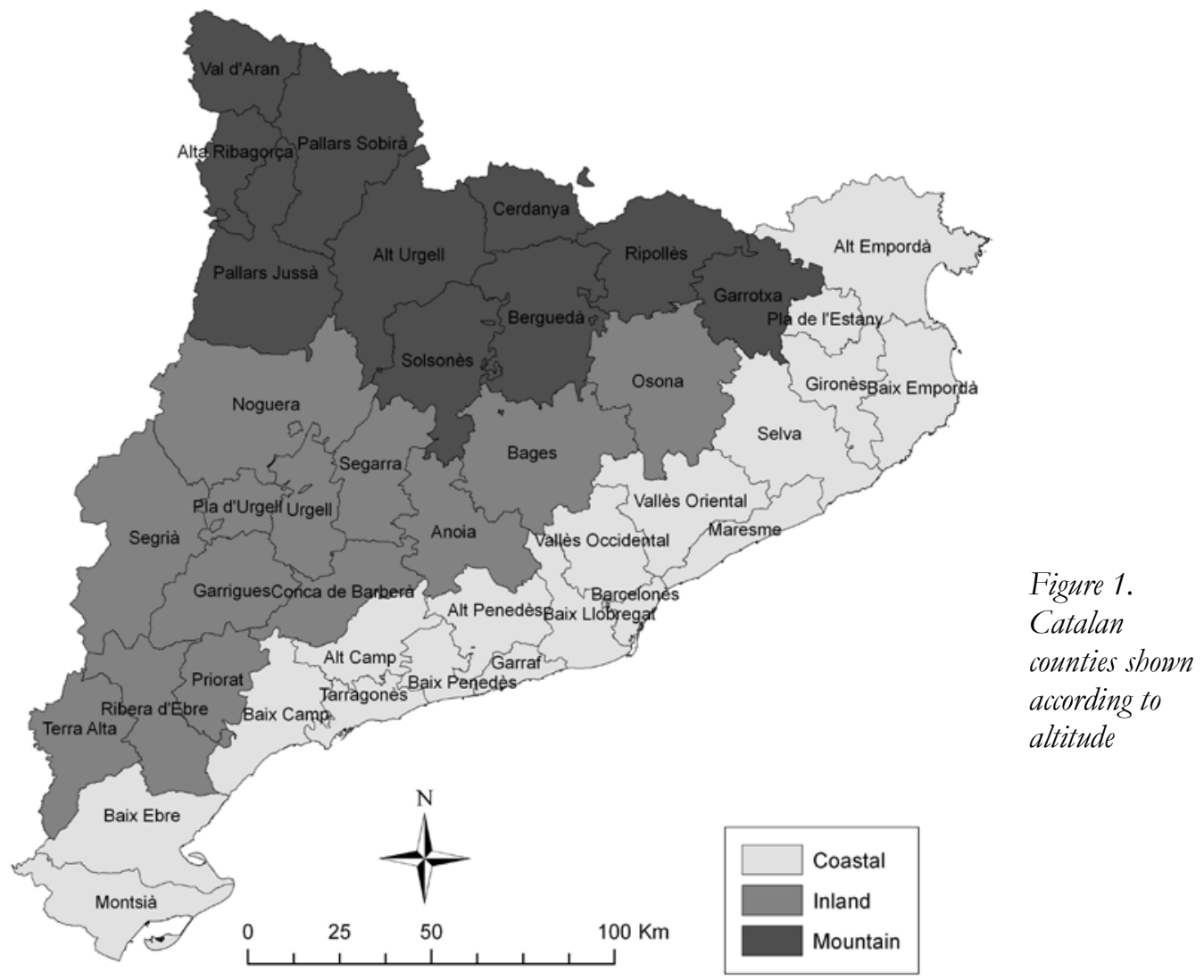

Catalan Waste Agency (ARC) website. Household and commercial collection is not accounted for separately in most Catalan municipalities. MSW is categorized according to what is collected separately for recycling or reuse (glass, paper, cardboard, plastic, organic waste, etc.) and what is transported to landfill or an incineration plant. The ratio between separate collection and total collection is also available.

The ARC also supplies data for daily waste generation per capita. However, these values only take into account the resident population. For this reason a new value for per capita waste generation has been calculated using the resident population as denominator but adding the seasonal population equivalent to annual full-time population (non-resident present population minus absent resident population). Data for this are available on the Catalan Statistical Institute (IDESCAT) website and cover not only tourists but also work and study mobility.

Five thresholds have been defined (Saladié 2011b) to compare differences among the forty-one counties and between each of them, taking into account the way waste generation per capita has been calculated: $<1 \mathrm{~kg} /$ day, $1-1.25 \mathrm{~kg} / \mathrm{day}, 1.26-1.50 \mathrm{~kg} / \mathrm{day}$, $1.51-1.75 \mathrm{~kg} /$ day and $>1.75 \mathrm{~kg} /$ day.

In order to determine the reasons that influence waste generation per capita in Catalan counties, I have selected a set of territorial, economic and demographic factors. These are altitude (mountain, inland plateau or littoral/pre-littoral) and population density for each county as territorial factors, income per capita and contribution of each activity sector to gross domestic product (GDP) as economic factors, and percentage of 
population over 64 as a demographic factor. All the data are available from the IDESCAT website, except contribution of each activity sector to GDP and altitude. For the former our source is the Anuari Economic Comarcal Catalunya Caixa (2011) and for the latter the distribution of counties has been performed according to our knowledge of Catalonia.

\section{Results and discussion}

The population in Catalonia increased at a higher rate than waste generation between 2000 and 2012. The reverse occurs in only five of the forty-one counties. There are ten counties in which waste generation in 2012 was lower than it was twelve years previously despite an increase in population. The figures were very different in 2007 (the peak in waste generation) when the population had increased at a rate 8 points lower than waste generation since 2000 (15.1\% and 23.7\% respectively). It would appear that the economic crisis may have contributed to a reduction in the amount of waste generated.

Waste generation per capita in Catalonia in 2012 was $1.35 \mathrm{~kg} /$ day, achieving the Catalan Government's target (PROGREMIC 2006). The results for the forty-one counties of Catalonia are shown in Figure 2. The best result was obtained in Terra Alta, with 0.97 $\mathrm{kg} /$ day. There is only one other county with a rate of less than $1 \mathrm{~kg}$ per capita (Garrigues: $0.99 \mathrm{~kg} / \mathrm{day}$ ). Both of these counties are located in the south-western area.

At the other extreme, three counties generated over $1.75 \mathrm{~kg} /$ day: Alt Empordà, Baix Empordà and Val d'Aran. The worst result corresponds to Val d'Aran (north-western area) with $2.26 \mathrm{~kg} /$ inhabitant/day, but the rate was also over $2 \mathrm{~kg}$ in the two counties located in north-eastern Catalonia. Municipal solid waste generation in 2012 was between 1.51 and $1.75 \mathrm{~kg} /$ day in five counties (Baix Penedès, Cerdanya, Garraf, La Selva and Tarragonès) and in another 14 it was between 1.26-1.50 (Alt Penedès, Anoia, Baix Camp, Baix Ebre, Berguedà, Conca de Barberà, Garrotxa, Maresme, Pallars Sobirà, Pla d’Urgell, Ribera d'Ebre, Ripollès, Solsonès and Vallès Oriental). The largest group of counties (seventeen) generated 1-1.25 kg/day: Alt Camp, Alt Urgell, Alta Ribagorça, Bages, Baix Llobregat, Barcelonès, Gironès, Montsià, Noguera, Osona, Pallars Jussà, Pla de l'Estany, Priorat, Segarra, Segrià, Urgell and Vallès Occidental.

The target set by the Catalan Government was achieved in thirty-three counties. Table 1 compares these results with those obtained in 2000 by Saladie (2011b), showing a clear improvement. In 2000 only $4.9 \%$ of Catalan people generated $\leq 1.25 \mathrm{~kg} /$ day, a value achieved by two-thirds of the resident population twelve years later. Meanwhile over $20 \%$ generated more than $1.50 \mathrm{~kg} /$ day in 2000 , a rate that had fallen to only $13 \%$ in 2012. The threshold accounting for the most people in 2000 was $1.25-1.50 \mathrm{~kg} / \mathrm{day}$ (almost three-quarters of the population of Catalonia), whereas in 2012 it was 1-1.25 $\mathrm{kg} /$ day $(66 \%)$.

I consider that in a region like Catalonia there is no socioeconomic, cultural or territorial factor to explain the difference between the waste generated by a resident in Val d'Aran and a resident in Terra Alta: $1.29 \mathrm{~kg} /$ day or almost $471 \mathrm{~kg} /$ year. Looking again at Figure 2 it must be noticed that the eight counties with the largest waste generation per capita $(>1.50 \mathrm{~kg} /$ day) are all located either in the Pyrenees (Ripollès and 
Val d'Aran) or near the Mediterranean Sea in two of the main tourist regions of Spain, the Costa Brava (Alt Empordà, Baix Empordà and La Selva) and the Costa Daurada (Baix Penedès, Garraf and Tarragonès). As mentioned in the introduction, tourism is one of the most important economic activities in Catalonia, especially coastal tourism in summer and skiing in winter, but the seasonal population is not taken into account when waste generation per capita is calculated. It may therefore explain to a great extent the differences between counties shown in Figure 2.

Table 1. Distribution of Catalan counties and population according to waste generation per capita in 2000 and 2012

\begin{tabular}{|c|c|c|c|c|}
\hline \multirow{2}{*}{$\begin{array}{l}\text { Generation per } \\
\text { capita }\end{array}$} & \multicolumn{3}{|c|}{2000} & \\
\hline & Counties & Population & Counties & Population \\
\hline$<1 \mathrm{~kg} /$ day & $00.0 \%$ & $00.0 \%$ & $04.9 \%$ & $00.4 \%$ \\
\hline $1-1.25 \mathrm{~kg} /$ day & $19.5 \%$ & $04.9 \%$ & $41.5 \%$ & $66.0 \%$ \\
\hline $1.26-1.50 \mathrm{~kg} /$ day & $43.9 \%$ & $74.3 \%$ & $34.1 \%$ & $20.6 \%$ \\
\hline $1.51-1.75 \mathrm{~kg} /$ day & $12.2 \%$ & $04.2 \%$ & $12.2 \%$ & $09.2 \%$ \\
\hline$>1.75 \mathrm{~kg} /$ day & $24.4 \%$ & $16.6 \%$ & $07.3 \%$ & $03.8 \%$ \\
\hline
\end{tabular}

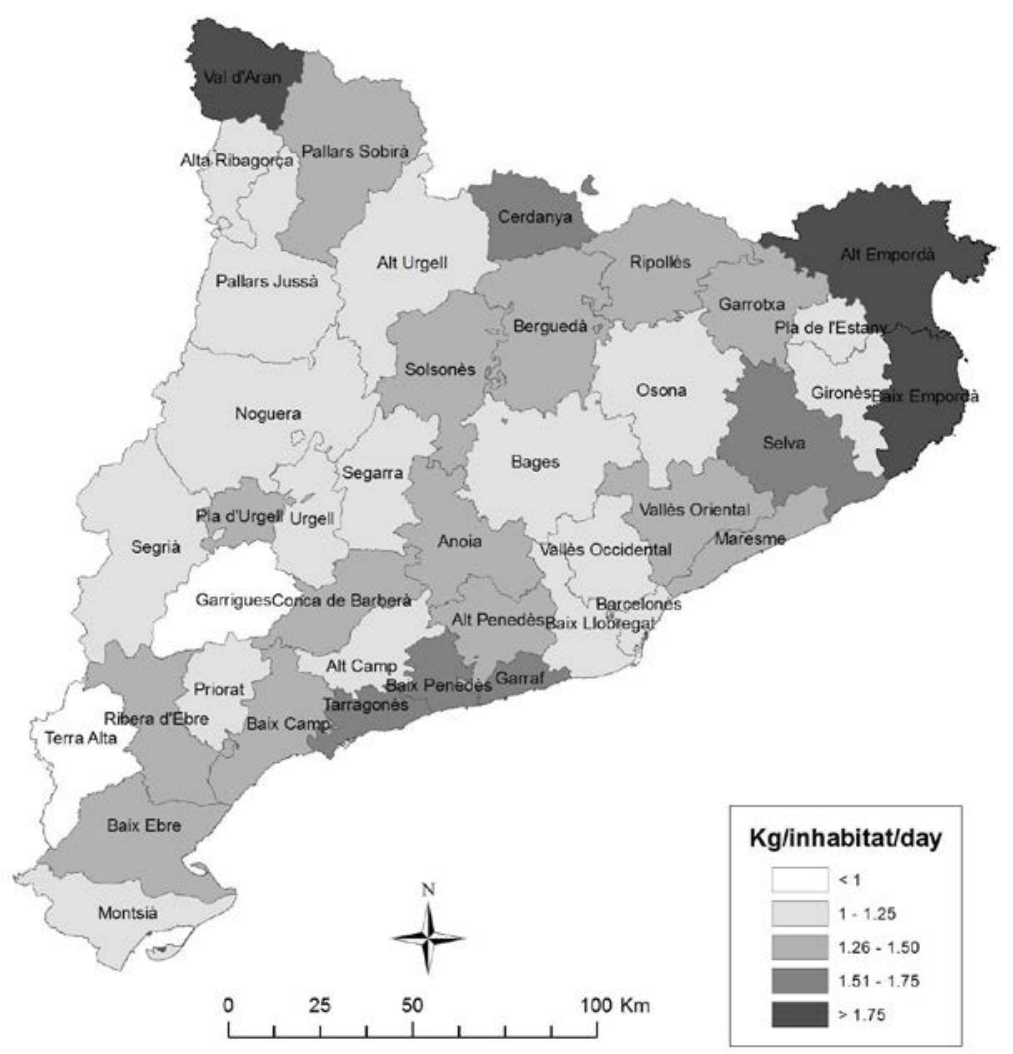

Figure 2. Municipal waste generation per capita in Catalan counties (2012): resident population

The Catalan Statistical Institute (IDESCAT) has estimated the seasonal population equivalent to annual full-time population for 2012. This value results from taking into 
account non-residents staying in Catalonia and residents absent from Catalonia. Work and study mobility are also included in the estimation together with tourists. According to IDESCAT, 154,371 people should be added to the total of Catalan residents. This means an increase of around $2 \%$ and therefore the rate of waste generation per capita decreases from 1.35 to $1.32 \mathrm{~kg} /$ day. However, there are substantial differences at county level. The value for seasonal population equivalent to annual full-time population is negative in thirteen counties. This means there are actually fewer people generating municipal waste than those registered. The biggest decreases in absolute numbers take place in Baix Llobregat and Vallès Oriental, with -25,225 and -24,010 fewer inhabitants respectively, i.e. $-3.1 \%$ and $-2.7 \%$ in relative numbers. Despite the fact that the population decrease in Anoia is only -3670, this value, like in the case of Baix Llobregat, accounts for $-3.1 \%$ of the registered population. Meanwhile an increase in population occurs in the other twenty-eight counties. The biggest can be found in Tarragonès $(+56,463)$, but the figure is over 20,000 in Alt Empordà, Baix Empordà, Baix Penedès and La Selva. All five counties are located on the Mediterranean coast. The biggest increase in relative numbers is in Cerdanya $(+33.7 \%)$ and is over $25 \%$ in Baix Empordà, Baix Penedès, Pallars Sobirà and Val d'Aran. This group comprises two counties located on the Mediterranean coast and three in the Pyrenees.

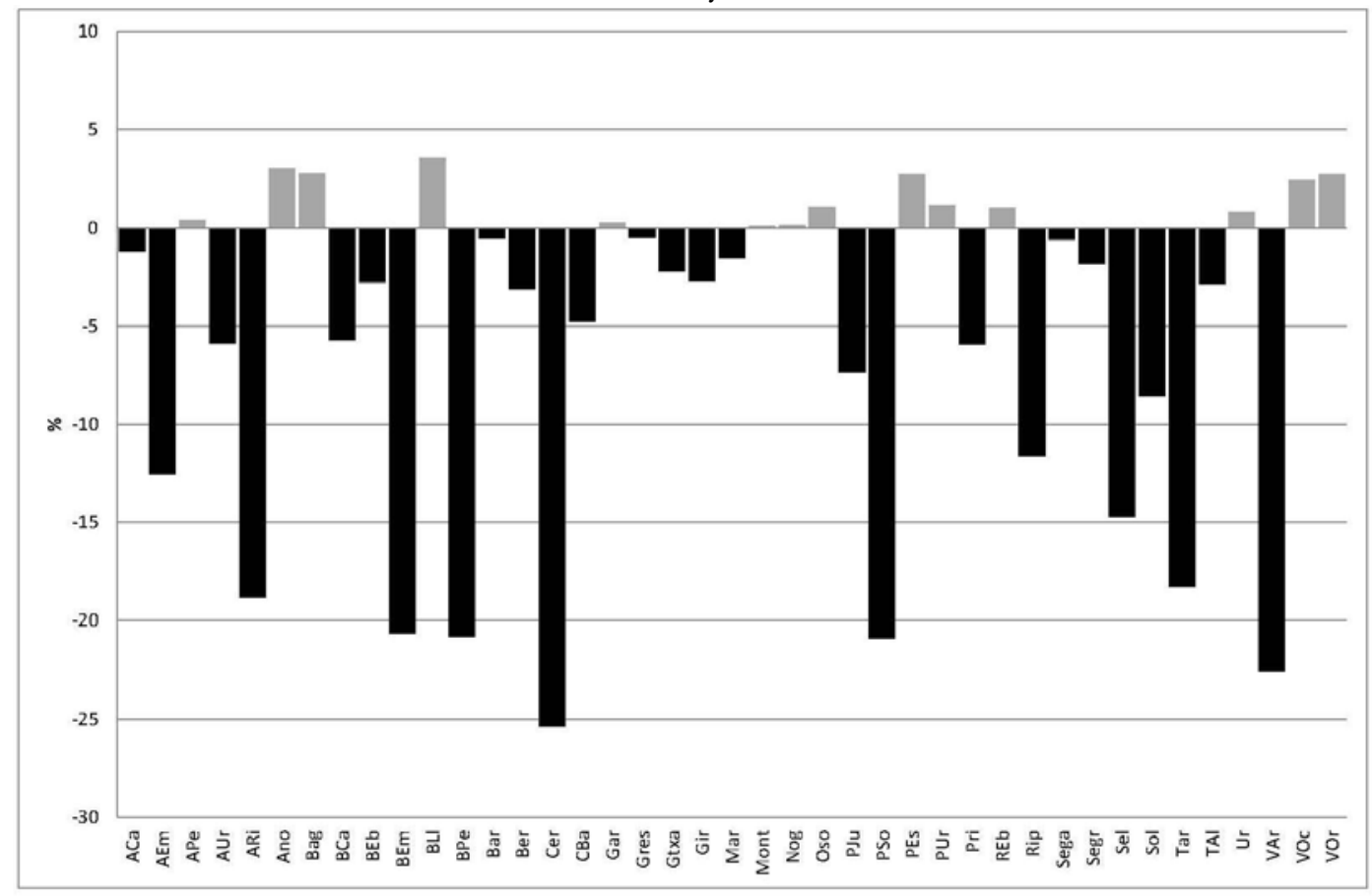

Figure 3. Municipal waste generation per capita increase/decrease after adding seasonal population to resident population

A new value for waste generation per capita has been obtained for each county after adjusting for the changes in population mentioned above. The value increases or decreases according to the seasonal population equivalent to annual full-time population 
added to the registered residents. The biggest decrease is in Val d'Aran, where waste generation per capita falls from 2.26 to $1.75 \mathrm{~kg} /$ day, followed by Baix Empordà (2.11 to $1.67 \mathrm{~kg} /$ day), Cerdanya (1.72 to $1.28 \mathrm{~kg} /$ day) and Baix Penedès (1.75 to $1.39 \mathrm{~kg} / \mathrm{day})$. At the other extreme there are Anoia and Baix Llobregat, both with slight increases (1.42 to $1.46 \mathrm{~kg} /$ day and 1.20 to $1.24 \mathrm{~kg} /$ day respectively). Figure 3 shows the differences in relative terms. A decrease of over $20 \%$ is found in six counties (Alta Ribagorça, Baix Empordà, Baix Penedès, Cerdanya, Pallars Sobirà and Val d'Aran), all of which have significant tourism activity. Four of these counties are located in the Pyrenees and the other two are on the coast.

The new distribution of waste generation per capita in the forty-one Catalan counties according to the same five thresholds is shown in Figure 4. The new results can be compared with those in Figure 2.

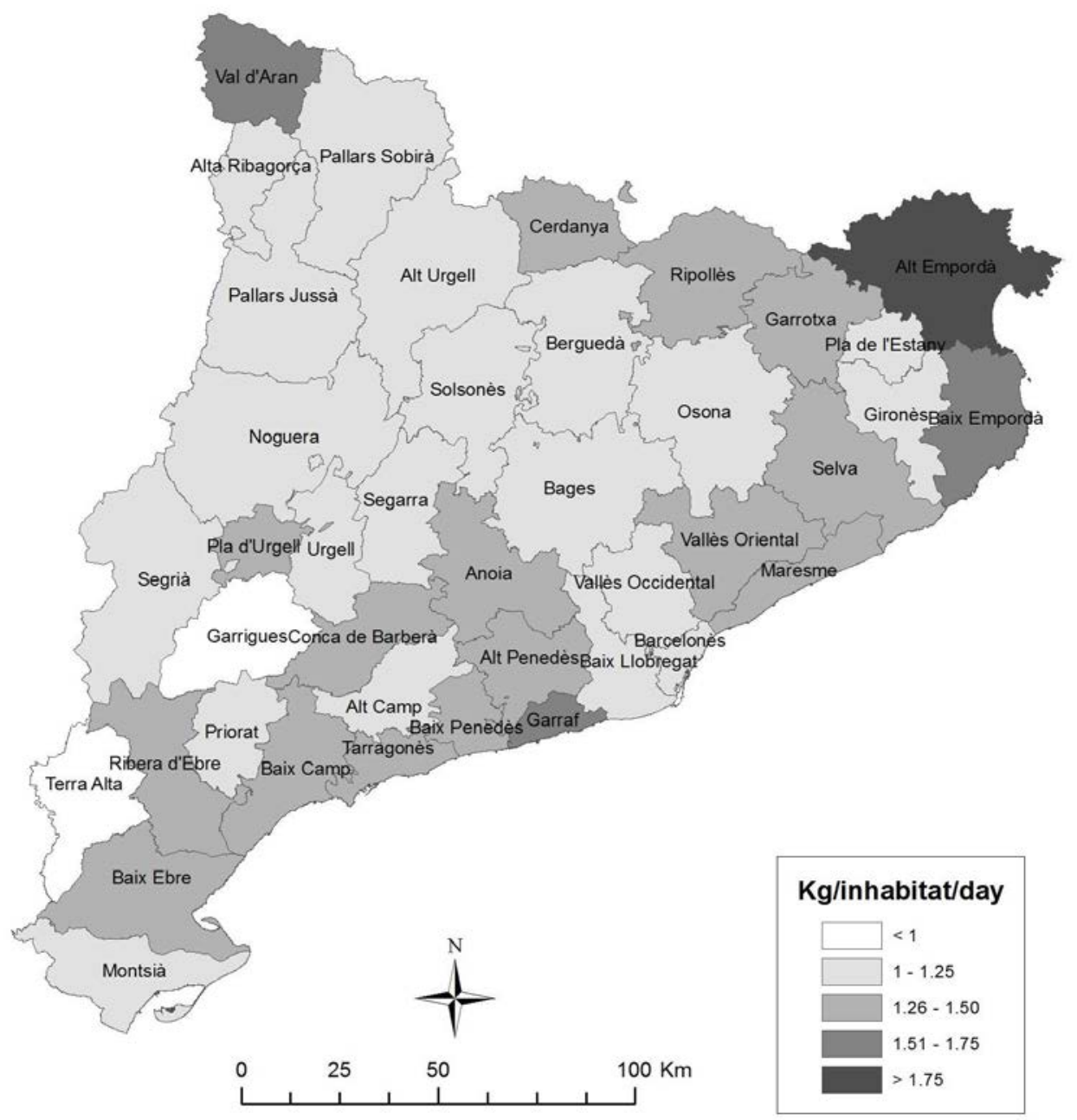

Figure 4. Municipal waste generation per capita in Catalan counties (2012): resident population plus seasonal population 
Terra Alta and Garrigues are again the only two counties below $1 \mathrm{~kg} / \mathrm{day}$. In both cases the value has declined slightly, down to 0.96 and $0.98 \mathrm{~kg} /$ inhabitant/day respectively. There is only one county with over $1.75 \mathrm{~kg} /$ inhabitant/day, while in Figure 2 there were three. Only Alt Empordà remains in the highest threshold in terms of waste generation per capita $(>1.75 \mathrm{~kg} /$ day), with $1.94 \mathrm{~kg} /$ day. Baix Empordà and Val d'Aran improve their results and move down to the next threshold (1.51-1.75 kg/inhabitant/day). A value for waste generation per capita of between 1 and $1.25 \mathrm{~kg} /$ inhabitant/day is achieved in twenty counties (Alt Urgell, Alta Ribagorça, Bages, Baix Llobregat, Barcelonès, Berguedà, Conca de Barberà, Gironès, Montsià, Noguera, Osona, Pallars Jussà, Pallars Sobirà, Pla de l'Estany, Priorat, Segarra, Segrià, Solsonès, Urgell and Vallès Occidental), whereas there were seventeen before. Finally, fifteen counties remain in the threshold of 1.26-1.50 kg/day: Alt Penedès, Anoia, Baix Camp, Baix Ebre, Baix Penedès, Cerdanya, Conca de Barberà, Garrotxa, Maresme, Pla d’Urgell, Ribera d'Ebre, Ripollès, La Selva, Tarragonès and Vallès Oriental.

Despite the fact that the differences between counties have been reduced, the difference between the highest value (Alt Empordà) and the lowest (Terra Alta) is almost $1 \mathrm{~kg} /$ inhabitant/day, so the seasonal population equivalent to annual full-time population data supplied by IDESCAT may have been underestimated. A decrease in waste generation per capita has occurred in twenty-eight counties. However, in only nine of them has the new value resulted in an improved threshold. In some cases the change has been from $>1.75 \mathrm{~kg} /$ day to $1.51-1.75 \mathrm{~kg} /$ day (Baix Empordà and Val d'Aran), while in other cases the change is from 1.51-1.75 to 1.26-1.50 kg/day (Baix Penedès, Cerdanya, Pallars Sobirà, La Selva and Tarragonès) or from $1.26-1.50 \mathrm{~kg} /$ day to $1-1.25 \mathrm{~kg} / \mathrm{day}$ (Berguedà and Solsonès). No threshold change has taken place in the case of the thirteen counties in which the use of the seasonal population equivalent to annual full-time population meant a decrease in population and therefore an increase in waste generation per capita.

Now that municipal waste generation per capita has been calculated by taking into account the seasonal population equivalent to annual full-time population, I can analyse its relation to territorial (altitude and population density), socioeconomic (income per capita and activity sectors' contribution to GDP) and demographic (people over 64) factors.

Figure 1 showed the distribution of counties according to altitude. More than 6.5 million people $(85.5 \%$ of the total) are located in the eighteen coastal counties. There are almost 1 million people $(11.4 \%)$ in the thirteen inland counties and only a quarter of a million $(3.1 \%)$ in the ten mountain counties. Figure 5 shows the same distribution taking into account population density. Only six counties have a very high density $(>500$ inhabitant $/ \mathrm{km}^{2}$ ) but they represent $62.3 \%$ of the population. Six other counties have a high density (200.1-500 inhabitant $/ \mathrm{km}^{2}$ ) but only represent $16.7 \%$ of the population. All these twelve counties are located in the coastal area. Thirteen counties have a low population density (50-200 inhabitant $/ \mathrm{km}^{2}$ ) and, like the previous group, represent $16.7 \%$ of the total population. Finally, population density is very low $(<50$ inhabitant $/ \mathrm{km}^{2}$ ) in sixteen counties, but these account for only $4.3 \%$ of the total population and most of them are located in mountain areas. 
Table 2 shows daily waste generation per capita taking into account population density and altitude in the forty-one Catalan counties. The lowest values are found in counties located in the inland area or with a low population density $(1.19 \mathrm{~kg} /$ inhabitant/day in both cases). The value is only $1.12 \mathrm{~kg} /$ day per capita in the seven counties that satisfy both variables. These seven counties with low population density located in the inland area are Conca de Barberà, Garrigues, Noguera, Priorat, Ribera d'Ebre, Segarra and Terra Alta.

At the other extreme, the highest values are found in counties with high population density $(1.35 \mathrm{~kg} /$ day $)$ or those located in the coastal area $(1.28 \mathrm{~kg} /$ day $)$. However, the values are very close to those found in counties with low population density or located in mountain areas respectively. The highest value $(1.50 \mathrm{~kg} /$ day $)$ when the two territorial factors are combined is to be found in counties located in the coastal area with low population density. These are Alt Camp, Alt Empordà, Alt Penedès, Baix Ebre, Montsià and Pla de l'Estany.

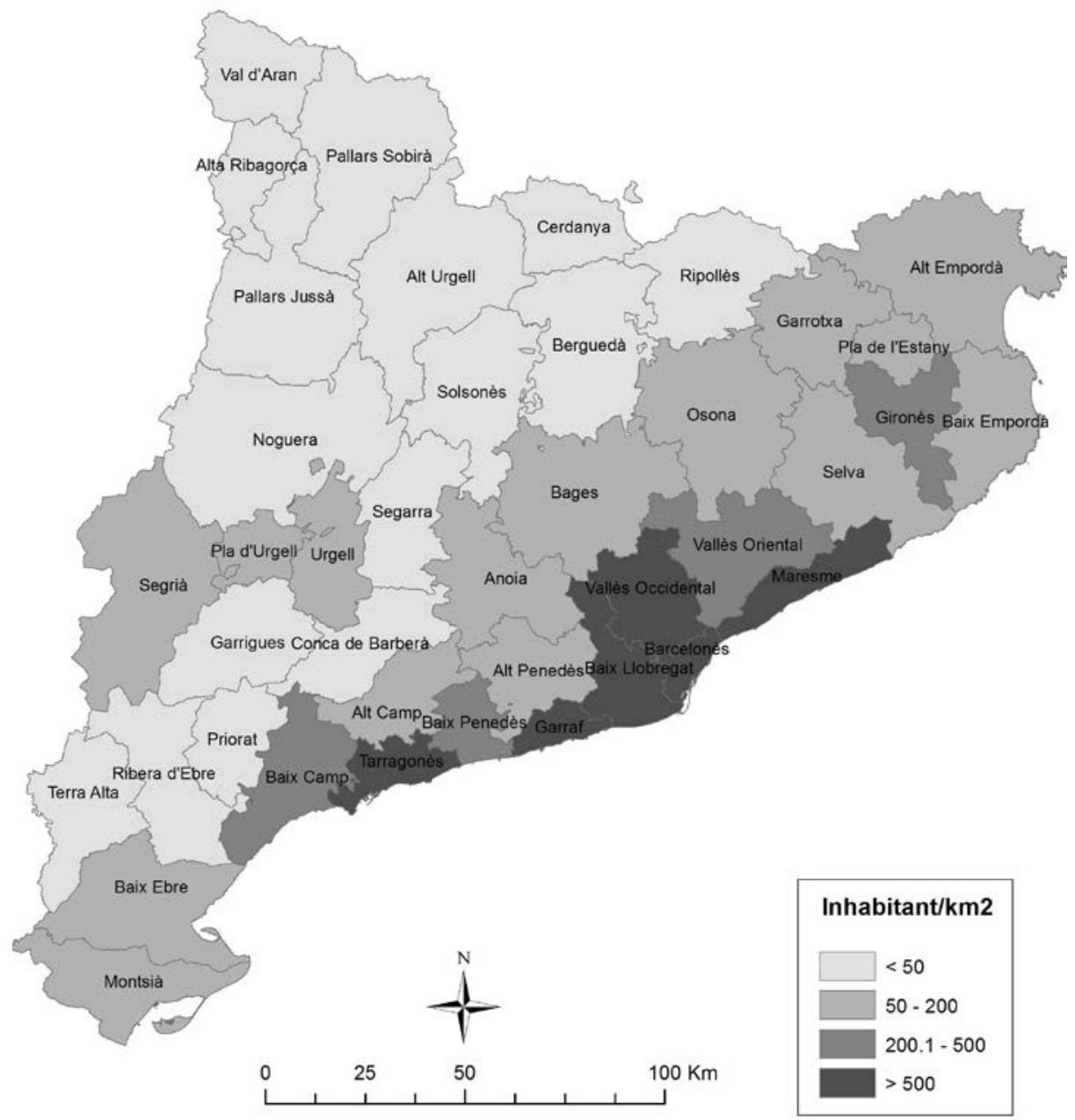

Figure 5. Distribution of Catalan counties according to population density 
Income per capita is one of the most frequently used economic factors when researching the relationship with waste generation per capita (Abu Qdais et al., 1997; Buenrostro et al., 2001; Gómez et al., 2008). Income per capita for Catalonia as a whole in 2010, the last available year, was 16,900€, ranging from 15,300€ in Anoia to 19,200€ in Val d'Aran. However, there is no correlation with waste generation per capita. Noguera and Alt Empordà have the same income per capita $(16,900 €)$ but their municipal waste generation per capita is 1.06 and $1.94 \mathrm{~kg} /$ day respectively. Looked at the other way around, the counties of Urgell and Osona have similar values for waste generation but income per capita is $18,200 €$ in the former and $15,700 €$ in the latter.

Table 2. Domestic waste generation and territorial attributes

\begin{tabular}{|crrr|}
\hline Population density & Generation per capita & Altitude & Generation per capita \\
Very low & $1.19 \mathrm{~kg} /$ day & Coastal & $1.28 \mathrm{~kg} / \mathrm{day}$ \\
Low & $1.32 \mathrm{~kg} /$ day & Inland & $1.19 \mathrm{~kg} / \mathrm{day}$ \\
High & $1.35 \mathrm{~kg} /$ day & Mountain & $1.27 \mathrm{~kg} / \mathrm{day}$ \\
Very high & $1.24 \mathrm{~kg} /$ day & & \\
\hline Density-Altitude & Generation per capita & Density-Altitude & Generation per \\
Low - coastal & $1.50 \mathrm{~kg} /$ day & Low - inland & $1.20 \mathrm{~kg} / \mathrm{day}$ \\
High - coastal & $1.35 \mathrm{~kg} /$ day & Very low - mountain & $1.26 \mathrm{~kg} / \mathrm{day}$ \\
Very high - coastal & $1.24 \mathrm{~kg} /$ day & Low - mountain & $1.31 \mathrm{~kg} / \mathrm{day}$ \\
Very low - inland & $1.12 \mathrm{~kg} /$ day & & \\
\hline
\end{tabular}

Income per capita is one of the most frequently used economic factors when researching the relationship with waste generation per capita (Abu Qdais et al., 1997; Buenrostro et al., 2001; Gómez et al., 2008). Income per capita for Catalonia as a whole in 2010, the last available year, was 16,900€, ranging from 15,300€ in Anoia to 19,200€ in Val d'Aran. However, there is no correlation with waste generation per capita. Noguera and Alt Empordà have the same income per capita $(16,900 €)$ but their municipal waste generation per capita is 1.06 and $1.94 \mathrm{~kg} /$ day respectively. Looked at the other way around, the counties of Urgell and Osona have similar values for waste generation but income per capita is $18,200 €$ in the former and $15,700 €$ in the latter.

The contribution of the different economic sectors to gross domestic product (GDP) is the second economic factor selected for an analysis of its possible relationship with municipal solid waste generation per capita. The strongest correlation $(+0.45)$ with waste generation per capita is found with the services sector's contribution to GDP. As can be seen in Figure 6 (counties highlighted for information purposes only), municipal waste generation per capita increases when the services sector's contribution to GDP also 
increases. Commercial activity plays an important role in the generation of waste, especially plastic, glass, paper and cardboard, regardless of whether or not they are collected separately. Meanwhile waste generation per capita decreases when the agricultural sector's contribution to GDP increases. There is a negative correlation ($0.45)$.

Finally, a negative correlation (-0.41) with municipal waste generation per capita is found if a demographic factor is analysed: population over 64. Waste generation per capita decreases when the percentage of people over 64 increases (Figure 7). Only 11.9\% of the Val d'Aran population is over $64(1.75 \mathrm{~kg} /$ inhabitant/day). The value reaches $26.6 \%$ in Terra Alta and $24.4 \%$ in Garrigues (0.94 and $0.96 \mathrm{~kg} /$ inhabitant/day respectively). This could be associated with a different consumption pattern of the elderly population. The results are statistically significant at a 95\% confidence level. These results are not enough to explain the differences in daily waste generation per capita in Catalonia. There are other determinants such as those indicated in the introduction. Some of them cannot be applied at a county level because there are no data. Behavioural patterns must also be taken into account. Furthermore, the seasonal population equivalent to annual full-time population data supplied by IDESCAT could have been underestimated in some cases.

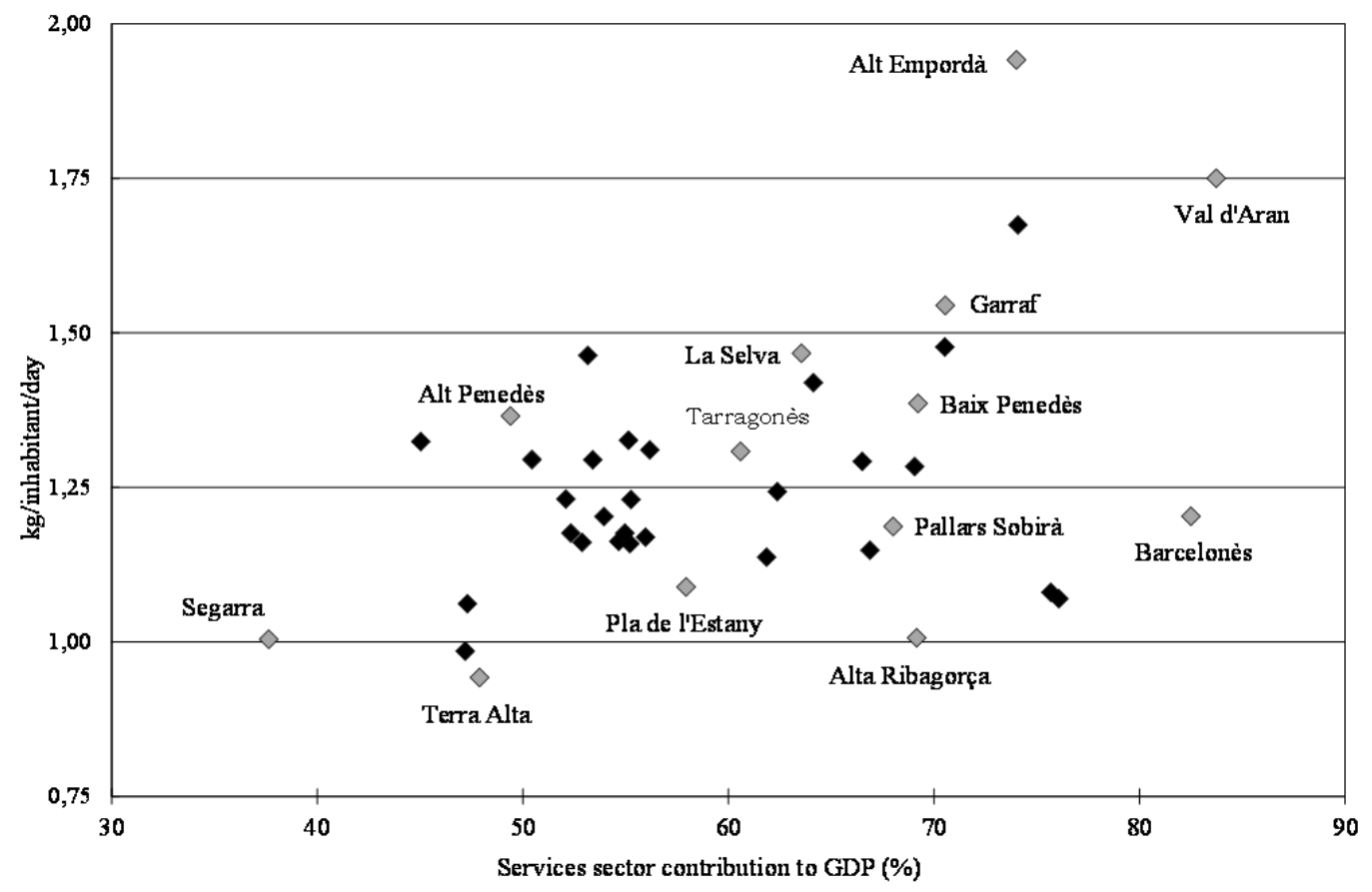

Figure 6. Municipal waste generation per capita and the services sector's contribution to GDP 


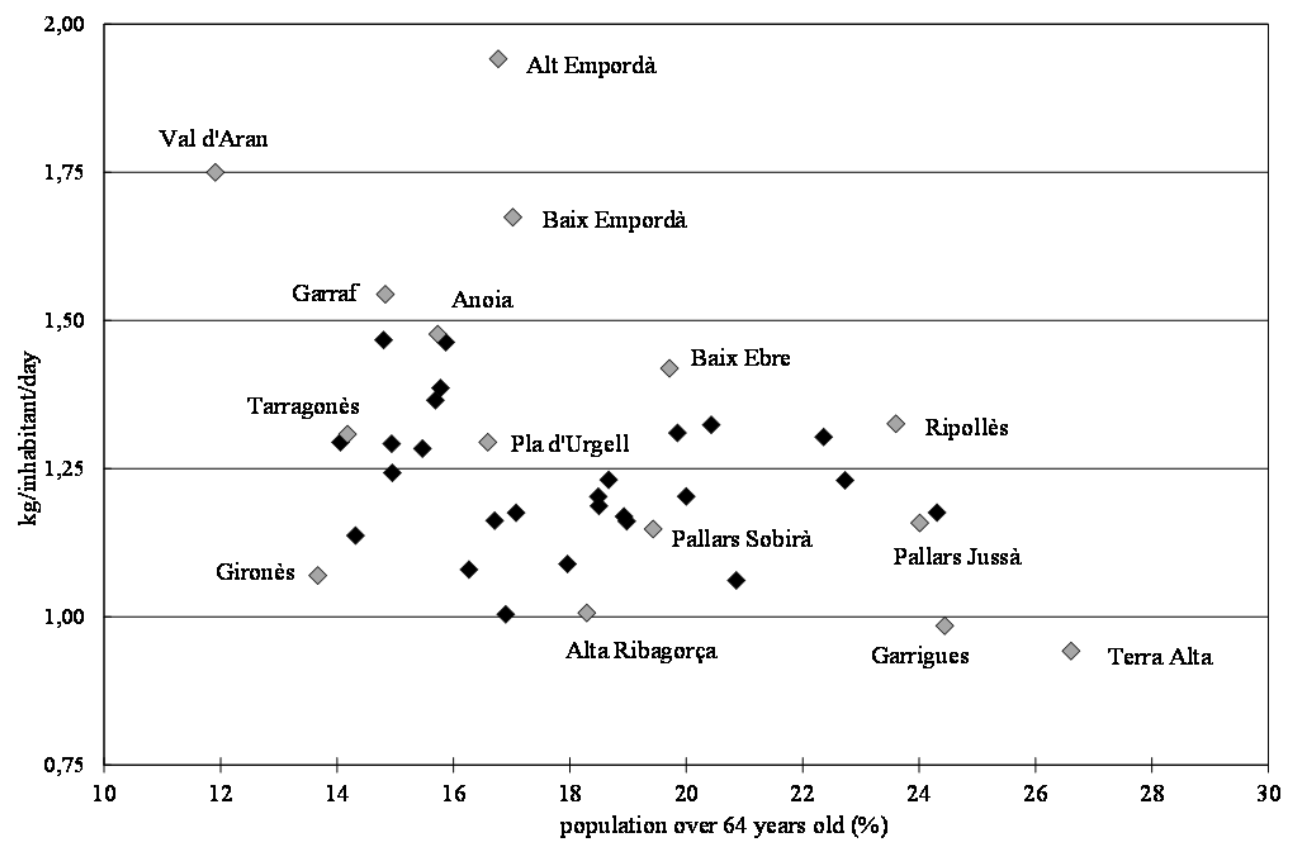

Figure 7. Municipal waste generation per capita and population over 64

\section{Conclusions}

The main objective of waste management policies is to prevent and reduce the generation of waste. Those in Catalonia (north-eastern Spain) are no exception and according to the Municipal Waste Management Program (PROGREMIC, 2006) developed by the Catalan Waste Agency (ARC), the target to be achieved in 2012 was $1.48 \mathrm{~kg} /$ day per capita. The result shows the program was a success because waste generation per capita in Catalonia in 2012 was $1.35 \mathrm{~kg} /$ day. It was $1.51 \mathrm{~kg} /$ day in 2000 but began to decrease in 2008, coinciding with the beginning of the economic crisis. The highest rate corresponds to 2007 with $1.64 \mathrm{~kg} /$ day.

There are considerable differences at local regional level (counties), ranging from 2.26 in Val d'Aran to $0.97 \mathrm{~kg} /$ day in Terra Alta. These differences are magnified because only the resident population is taken into account in the ARC database, and work and study mobility as well as tourists play an important role in some counties. A new value has been calculated by adding the seasonal population equivalent to annual full-time population (non-resident current population minus absent resident population - data available from the IDESCAT website) to the resident population. Twenty-eight counties have increased their population, six of them by over $20 \%$. In thirteen counties the population has decreased, but in none of them by more than $-5 \%$.

The consequence of this is an increase or decrease in waste generation per capita. Increases are only slight, but in seven counties the decrease in waste generation per capita is over $-15 \%$. These are counties with a relevant tourist activity, located on the Mediterranean coast (Baix Empordà, Baix Penedès and Tarragonès) or in the Pyrenees (Alta Ribagorça, Cerdanya, Pallars Sobirà and Val d'Aran). 
Terra Alta again shows the lowest value with $0.96 \mathrm{~kg} /$ inhabitant/day, while the highest value corresponds to Alt Empordà (1.94 kg/inhabitant/day). In both cases waste generation has fallen and the difference between them has narrowed, although it is still over $350 \mathrm{~kg} /$ inhabitant/year). The distribution of the counties into five thresholds shows that only two of them (Terra Alta and Garrigues) are under $1 \mathrm{~kg} / \mathrm{day}$. The largest group includes twenty counties where waste generation per capita is $1-1.25 \mathrm{~kg} / \mathrm{day}$, followed by fifteen with 1.26-1.50 kg/day. In only four counties does the value exceed $1.50 \mathrm{~kg} / \mathrm{day}$ (Alt Empordà, Baix Empordà, Garraf and Val d'Aran). The differences suggest that the seasonal population equivalent to annual full-time population data supplied by IDESCAT could have been underestimated in some cases.

Several territorial, socioeconomic and demographic factors have been analysed so as to explain the differences that arise between the counties. It has been shown that differences in municipal waste generation are linked to territorial factors such as altitude and population density. The counties with the lowest rates are located in inland areas and have a very low population density $\left(<50\right.$ inhabitant $\left./ \mathrm{km}^{2}\right)$. Meanwhile the highest rates correspond to counties located on the coast but with a low population density.

This reinforces the doubts surrounding the suitability of using the seasonal population equivalent to annual full-time population data because in the first group economic activity is not so important, whether tourism or commercial. At the same time there is a positive correlation $(+0.45)$ between municipal waste generation per capita and the services sector's contribution to GDP, whereas it is negative $(-0.45)$ in the case of the agricultural sector. Municipal solid waste generation per capita is higher in counties with a high contribution of the services sector to GDP. However, there is no correlation between daily waste generation per capita and income per capita. This is the opposite of what has been detected in other regions according to the literature mentioned in the introduction. Finally, there is a negative correlation between daily waste generation per capita and the percentage of people over 64 (-0.41). This could be associated with different patterns of consumption of the elderly population

The seasonal population, especially in tourist regions like Catalonia or Spain as a whole, must be taken into account when designing waste management programs, particularly when a target for waste generation per capita is defined. This needs to be a preliminary step before any in-depth analysis of the reasons behind the differences between rates can be carried out. Waste management policies should be based on reliable waste generation per capita data.

The main objective for the future will be to calculate a new value for the seasonal population equivalent to annual full-time population. This will allow us to carry out a more accurate analysis of the differences in waste generation per capita among the Catalan counties and to assess the determinants of waste generation (territorial, socioeconomic or demographic variables), as has been shown in the literature. A second objective would be to perform the same analysis but at municipality level.

\section{Acknowledgments}

This work was supported by the Dow/URV Chair of Sustainable Development and the Spanish Ministry of Economy and Competitiveness (MOVETUR CSO2014- 
51785-R). The author wishes to thank the Serra Húnter Programme of the Catalan Government.

\section{References}

Abu Qdais, H., Hamonda, M.F. and Newham, J. (1997) 'Analysis of residential solid waste at generation sites', Waste Management \& Research, Vol. 15, pp. 395-406.

Assamoi, B. and Lawryshyn, Y. (2012) 'The environmental comparison of landfilling vs. Incineration of MSW accounting for waste diversion', Waste Management, Vol. 32, pp. 1019-1030.

Atencio Pérez, R.M., Reyes-López, J.A. and Guevara-García, J.A. (2013) 'Evaluación de riesgo ambiental en un tiradero con quema de basura', Revista Internacional de Contaminación Ambiental, No 29, pp. $107-$ 117.

Bautista, J. and Pereira, J. (2006) 'Modelling the problem of locating collection areas for urban waste management. An application to the metropolitan area of Barcelona', Omega, No 34, pp. 617-629.

Beigl, P., Lebersorger, S. and Salhofer, S. (2008) 'Modelling municipal solid waste generation: a review', $W$ aste Management, Vo. 28, pp. 200-214.

Bernardes, C. and Günther, W.M.R. (2014) 'Generation of domestic solid waste in rural areas: case study of remote communities in the Brazililan Amazon', Human Ecology, Vol. 42, pp. 617-623.

Boer, E. den, Jedrczak, A., Kowalski, Z., Kulczycka, J. and Szpadt, R. (2010) 'A review of municipal solid waste composition and quantities in Poland', Waste Management, Vol. 30, pp. 369-377.

Bovea, M.D., Ibáñez-Forés, V., Gallardos, A. and Colomer-Mendoza, F.J. (2010) 'Environmental assessment of alternative municipal solid waste management strategies. A Spanish case study', Waste Management, Vol. 30, pp. 2383-2395.

Buenrostro, O., Bocco, G. and Bernache, G. (2001) 'Urban solid waste generation and disposal in Mexico: a case study'. Waste Management and Research, Vol. 19, pp. 169-176.

Buenrostro, O. and Bocco, G. (2003) 'Solid waste management in municipalities in Mexico: goals and perspectives', Resources, Conservation and Recycling, Vol. 39, pp 251-263.

Catalunya Caixa (2011) Anuari economic comarcal. Catalunya Caixa. Available in http//:www.caixacatalunya.com/anuari2010.

Chowdhury, M. (2009) 'Searching quality data for municipal solid waste planning', Waste Management, Vol. 29, pp. 2240-2247.

Cole, C., Quddus, M., Wheatley, A., Osmani, M. and Kay, K. (2014) 'The impact of Local Authorities' interventions on household waste collection: a case study approach using times series modelling', Waste Management, Vol. 34, pp. 266-272.

Dahlén, L., Aberg, H., Lagerkvist, A. and Berg, E.O. (2009) 'Inconsistent pathways of household waste', Waste Management, Vol. 29, pp. 1798-1806.

Direcció General de Turisme (2013). Catalunya turística en xifres 2011. Departament d'Empresa i Ocupació de la Generalitat de Catalunya, Barcelona.

De Feo, G. and Williams, I.D. (2013) 'Siting landfills and incinerators in areas of historic unpopularity: surveying the views of the next generation', Waste Management Vol. 33, pp. 2798-2810.

Ersoy, H., Bulut, F. and Berkün, M. (2013) 'Landfill site requirements on the rock environment: a case study', Engineering Geology, Vol. 154, pp. 20-35.

Gellynck, X., Jacobsen, R. and Verhelst, P. (2011) 'Identifying the key factors in increasing recycling and reducing residual household waste: a case study of the Flemish region of Belgium', Journal of Environmental Management, Vol. 92, pp. 2683-2690.

Gentil, E.C., Gallo, D. and Christensen, T.H. (2011) 'Environmental evaluation of municipal waste prevention', Waste Management, Vol. 31, pp. 2371-2379.

Getahun, T., Mengistie, E., Haddis, A., Wasie, F., Alemayehu, E., Dadi, D., Van Gerven, T. and Van der Bruggen, B. (2012) 'Municipal solid waste generation in growing urban areas in Africa: current practices and relation to socioeconomic factors in Jimma, Ethiopia', Environmental Monitoring and Assessment, Vol. 184, pp. 6337-6345.

Goddard, H.C. (1995) 'The benefits and costs of alternative solid waste management policies', Resources, Conservation and Recycling, Vol. 13, pp. 183-213. 
Gomez, G., Meneses, M., Ballinas, L. and Castells, F. (2008) 'Characterization of urban solid waste in Chihuahua, Mexico', Waste Management, Vol. 28, pp. 2465-2471.

Greene, K.L. and Tonjes, D.J. (2014) 'Quantitative assessments of municipal waste management systems: using different indicators to compare and rank programs', Waste Management, Vol. 34, pp. 825-836.

Hockett, D., Lober, D.J. and Pilgrim, K. (1995) 'Determinants of per capita municipal solid waste generation in the Southeastern United States', Journal of Emironmental Management, Vol. 45, pp. 205-217.

Keser, S., Duzgun, S. and Aksoy, A. (2012) 'Aplication of spatial and non-spatial data analysis in determination of the factors that impact municipal solid waste generation rates in Turkey', Waste Management, Vol. 32, pp. 359-371.

Khadivi, M.R. and Fatemi Ghomi, S.M.T. (2012) 'Solid waste facilities location using of analytical network process and data envelopment analysis approaches', Waste Management, Vol. 32, pp. 1258-1265.

Lebersorger, S. and Beigl, P. (2011) 'Municipal solid waste generation in municipalities: quantifying impacts of household structure, commercial waste and domestic fuel', Waste Management, Vol. 31, pp. 1907-1915.

Mateu, J. (2003) 'Turismo residencial y dispersió urbana en Mallorca (Illes Balears). Un ensayo metodológico en el municipio de Pollença', Estudios Turísticos, No. 155-156, pp. 197-218.

Mendes, M.R., Aramaki, T. and Hanki, K. (2004) 'Comparison of the environmental impact of incineration and landfilling in Sao Paula City as determined by LCA’. Resources, Conservation and Recycling, Vol. 41, pp. 47-63.

Morselli, L., de Robertis, C., Luzi, J., Passarini, F. and Vassura, I. (2008) 'Environmental impacts of waste incineration in a regional system (Emilia Romagna, Italy) evaluated from a life cycle perspective', Journal of Hazardous Materials, Vol. 159, pp. 505-511.

Passarini, F., Vassura, I., Monti, F., Morselli, L. and Villani, B. (2011) 'Indicators of waste management efficiency related to different territorial conditions', Waste Management, Vol. 31, pp. 785-792.

Perea-Milla, E., Marí-Pons, S., Rivas-Ruiz, F., Gallofré, A., Navarro-Jurado, E., Navarro-Ales, M.A., Jimenez-Puente, A., Fernandez-Nieto, F., March-Cerdà, J.C., Carrasco, M., Martin, L., LopezCano, D., Gutierrez, G.E., Cortes-Macías, R. and Garcia-Ruiz, A.J. (2007) 'Estimation of the real population and its impact on the utilisation of healthcare services in Mediterranean resort regions: an ecological study'. BMC Health Services Research, Vol. 7: 13.

PROGREMIC (2006) Programa de Gestió de Residus Municipals a Catalunya 2007-2012. Agència de Residus de Catalunya, Generalitat de Catalunya. Available in http://www.arc.cat.

Purcell, M. and Magette, W.L. (2009) 'Prediction of household and commercial BMW generation according to socio-economic and other factors for the Dublin region', Waste Management, Vol. 29, pp. 12371250.

Oribe-Garcia, I., Kamara-Esteban, O., Martin, C. and Macarulla-Arenaza, A.M. (2015) 'Identification of influencing municipal characteristics regarding household waste generation and their forecasting ability in Biscay', Waste Management, Vol. 39, pp. 26-34.

Qu, X., Li, Z., Xie, X., Sui, Y., Yang, L. and Chen, Y. (2009) 'Survey of composition and generation rate of household wastes in Beijing, China', W aste Management, Vol. 29, pp. 2618-2624.

Sajani, S.Z., Scotto, F. and Lauriola, P. (2005) 'A direct approach to control short term population dynamics in time series studies’ Journal of Epidemiology Community Health, Vol. 59, pp. 985-986.

Saladié, O. (2011a) 'La gestión de los residuos domésticos en los antiguos vertederos de la comarca de La Ribera d'Ebre (Cataluña)', Investigaciones geográficas, No 56, pp. 177-197.

Saladié, O. (2011b) Los residuos domésticos y asimilables en Cataluña: la generación y la recogida selectiva como indicadores de la sostenibilidad territorial', Boletín de la Asociación de Geógrafos Españoles, No 56, pp. 321-347.

Salhofer, S., Obersteiner, G., Schneider, F. and Lebersorger, S. (2008) 'Potentials for the prevention of municipal solid waste', Waste Management, Vol. 28, pp. 245-249.

Shekdar, A.V. (2009) 'Sustainable solid waste management: an integrated approach for Asian countries', Waste Management, Vol. 29, pp. 1438-1448.

Sterner, T. and Bartelings, H. (1999) 'Household waste management in a Swedish municipality: determinants of waste disposal, recycling and composting, Environmental and Resources Economics, Vol. 13, pp. 473-491. 